\title{
Friendly Encounters with Literary Animals
}

McHugh, Susan, et al., eds. The Palgrave Handbook of Animals and Literature. Cham, Switzerland: Palgrave Macmillan, 2021. 636 pages. ISBN 978-3-030-39772-2. E-book. $€ 117.69$.

Borbála László

https://doi.org/10.30608/HJEAS/2021/27/2/17

For its best part, literary criticism has been devoid of a creature-conscious, let alone creaturecentered, perspective. Animals, animality, and human-animal encounters have been interpreted as metaphors, allegories, or other literary devices serving as transparent objects through which humans could project ideas about themselves. One could also say that such a tradition imagines interpretation as a hunt whereby textual animals function as hunting dogs that help the reader track down the text's “true" meaning. As Jacques Derrida said at the 1997 Cerisy Conference, a cornerstone for literary animal studies, the animal's ontological status as "being-there-beforeme" also entails that "it is behind me," and as such, "it can allow itself to be looked at" (11). However, as he continues, this view perpetuated by Western philosophy forgets that we are animals too and that other creatures can also look at us, thereby supplementing cross-species encounters with their own vantage points. Derrida's notions of human animality and animal subjectivity thus make it impossible to answer the question of who is following whom in the ontological order of things, or to emphasize a creature-conscious perspective when it comes to reading literature. This viewpoint, which one could also call relational, was endorsed by "the animal turn" in the decade following the Cerisy Conference and has since extended the scope of literary criticism.

Following the implications of Derrida's deconstructive theory and the objectives of the “animal turn," The Palgrave Handbook of Animals and Literature, edited by Susan McHugh, Robert McKay, and John Miller, aims to reread canonical texts within and beyond English 
literature from a more-than-human perspective. The carefully collected articles all acknowledge the animating force with which animals contribute to creating our texts and contexts, as opposed to being passively implicated by them. In this manner, by foregrounding a sense of relationality, the book, in Anat Pick's terms, dehumanizes (6) and, I would add, reanimalizes the humanities. The series titled Palgrave Studies in Animals and Literature has already made a significant progress in this regard by presenting selected studies of animal representations from the Middle Ages to the present, but its latest volume also attempts to give an overview of the history of literary animal studies to date. As such, the handbook joins and, at the same time, records and reflects on the long-needed process of doing away with humanocentric reading practices.

To this end, the volume's structure follows the historical development of literary animal studies. The first major block, incorporating five chapters, enlightens the reader on the field's theoretical foundations, beginning with the introduction of some of the key terms that are recurrently employed throughout the whole book. It is vital that before delving into individual texts and theses, readers can learn about such basic concepts as anthropocentrism, human exceptionalism, and anthroponormativity, since these are the patterns of thought that have perpetuated the notion of literature being exclusively human, meaning that only human beings can influence the meaning, be the subject as well as the audience of literature, while animals can only be its objects. In other words, the chapters in the theoretical block elucidate how anthropocentrism as a dominant strand in Western thought has consolidated a reading tradition which, in my view, can best be grasped in terms of a hunt - the imagery that has been suggested in the opening section of this review.

In The Celestial Hunter (2016), Roberto Calasso argues that "the hunter is the man of negation [who] exists insofar as he negates an initial situation" (n.pag.), referring to the situation of being prey as opposed to being a predator that he transformed himself into at a pivotal moment in history, denying his animal origins thenceforth. The reading conventions which 
construe animals only as metaphors thus follow the logic of hunting, that is, the logic of denial, since they negate the creatural and, by extension, relational nature of literary texts. To complete, as it were, this lack in traditional reading practices, the authors of the volume take on an approach delineated in the second chapter, titled "Metaphor, Metonymy, More-ThanAnthropocentric. The Animal That Therefore I Read (and Follow).” Sofie-Ann Lönngren proposes a novel way of reading literary animals by combining two existing traditions: the symptomatic, which "suspects the text of hiding its 'true' meaning in its depths" and thus focuses on the metaphoric or allegorical meanings of animals (39); and the surface, which contends that texts have several, horizontally organized meanings, therefore treating the animal as metonymy, a rhetorical figure that can aptly signify the actual animal (41). In fact, the third, combined reading strategy, which Lönngren calls "following" - aiming to invert Derrida's notion of man following animals on the evolutionary scale, thereby affirming the right of man to subjugate animals — has already been formulated by writer, poet, painter, and art critic John Berger, who accentuates the "animal's character of simultaneousness." For him, the creature is "both a material organism with its own agency and phenomenology, separate from the human and her experiences, and part of a human epistemological system" (qtd. in Lönngren 43). The combined approach proves to be the backbone of the whole handbook, which reads animal characters not only as literary presences, but also as examples of their own phenomenological reality, as material presences, thereby foregrounding the notion that living, breathing, flesh and bone creatures co-create "our" literary representations.

The second main block is organized into seven minor sections, each dedicated to a certain period of literary history from medieval to contemporary literature. Enacting the guidelines laid down in the theoretical section, the individual (altogether thirty-one) chapters in this block not only read through the anthropocentric worldviews in which the analyzed texts were born, but also expand the scope of criticism, which formerly tended to favor 
humanocentric interpretations. The result is an extensive collection of simultaneously dehumanized and reanimalized readings of texts within and beyond the English literary canon. Some of the chapters highlight the concept of human animality, that is, our shared corporeality with non-human animals, most saliently manifested in the tropes of vulnerability and death (see, for example, Karen Raber's chapter on the phenomenology of the horse-human bond in Henry $V$ or Anat Pick's analysis of creatureliness in Dezső Kosztolányi’s Skylark). Other studies focus on animal subjectivity rendered in an explicit, albeit arguably anthropomorphized, manner, for instance in stories narrated from an animal's point of view (for the latter, see Marianne DeKoven's chapter "Virginia Woolf and Gertrude Stein: Two Modernist Women Writing as Dogs"). Yet the chapters that add the most to literary criticism are those which seemingly do very little: the ones that simply appreciate how much the meaning of a text owes to the presence of creatures. The authors of these chapters suggest that disregarding the relational nature of literature is a negation, since without animal figures, and without the actual animals they stand for, texts would not be the same, would lack something vital, or maybe would not even exist.

The latter idea finds direct expression in Margaret Cavendish's early modern poem "Hunting of the Stag," as presented within the frame of Karl Steel's chapter "Huntings of the Hare: The Medieval and Early Modern Poetry of Imperiled Animals" (149). As Steel points out, the stag resists to be read in metaphorical terms because the poem "starts and ends with the stag, his life, his joy in his body, and, at last, his collapse under the relentless expertise of dogs and hunters" (149). Steel argues that recognizing literary animals as more than mere symbols grants animal experience value in itself and "with Cavendish, that recognition can go so far as to collapse any difference between living poet and dying animal" (150). Since the poet, the poem, and the animal are rendered one and the same, "Hunting of the Stag" performs the notion that there would be no literature without actual creatures and the experiences they bring from their own phenomenological realities. 
Michael Malay's chapter titled “John Keats and the Sound of Autumn: Reading Poetry in a Time of Extinction" offers the most poignant demonstration of an imagined yet warning absence of creatures in literature from the perspective of the anthropocene's present stage. Malay invites the reader to consider the effects of mass extinction through a thought-experiment that he actually puts to practice by cutting out all lines from poems by Romantic poets that mention an insect. The "redacted" texts visualize how changes to an environment lead to alterations in cultural meaning; the black gaps in the poems stand for "aporias of experience that open up when a particular species disappears" (295). One of Malay’s examples is Keats's sonnet "On the Grasshopper and Cricket," in which the grasshopper is "an emanation of summer itself," its voice, presence, experience intricately intertwined with those of the season. Therefore, when Malay removes the grasshopper from the poem, "the collocation between "grasshopper" and "summer" breaks down, and, as it disappears, it alters our sense of the whole, by weakening the poem's range of meanings, experiences and associations" (296-97). The sonnet becomes less not only in its aesthetic totality, but also in its meaning. Besides "reading by redaction," close reading is proposed as another useful means to recognize that the material presence of other animals completes metaphoric meaning. Through slow reading attentive to detail and complexity, Malay notices that in Keats's ode "To Autumn," the most important verb "sing" is given not to the songbirds that are usually associated with music, but to the seemingly insignificant hedge-cricket, whose chirping is perceived as an essential part of the autumn field's presence. As Malay rhetorically concludes, "without it, the poem seems to ask, could we recognise autumn as autumn?" (303).

The five chapters in the book's last major block titled "New Directions" connect literary animal studies with biopolitics, disability studies, medical humanities, and environmental humanities, thus promoting the notion of relationality beyond the realm of literature. Still, the most important task that the volume undertakes "is to cultivate critical practices that remain 
anchored to the unapprehendable, or partially apprehendable, qualities of animal being and the ethical demands they make of us" (617). As the closing lines of the last chapter assert, "[t]his, ultimately, is what literary animal studies is for" (617). Therefore, the book's biggest achievement concerns a specific attitude towards literature, a closer attention to animals' material, experiential presence in texts, a complementary reading of what has been formerly construed as human. I believe the reading strategies proposed and applied in the volume convincingly highlight the role of all creatures' phenomenological reality in creating metaphoric meaning. Without them, indeed, without this book, literary criticism would still be a negation, a violent hunt for human meaning. Students and teachers engaged in a friendlier, more-than-human reading of texts will surely find The Palgrave Handbook of Animals and Literature a volume of great value.

University of Debrecen

\section{Works Cited}

Calasso, Roberto. The Celestial Hunter. Trans. Richard Dixon. E-book. Farrar, Straus and Giroux, 2020.

Derrida, Jacques. The Animal That Therefore I Am. Ed. Marie-Luise Mallet. Trans. David Wills. New York: Fordham UP, 2008. Print.

Pick, Anat. Creaturely Poetics: Animality and Vulnerability in Literature and Film. New York: Columbia UP, 2011. Print. 